\title{
GARRAPATAS DE CATAMARCA Y TUCUMÁN: ESTUDIO DE UNA COLECCIÓN DE HOSPEDADORES SILVESTRES Y DOMÉSTICOS
}

\author{
ZeRPA, C. ${ }^{1}$, VenzaL, J. M. ${ }^{2}$, LÓPEZ, N. ${ }^{3}$ \\ Mangold, A. J. ${ }^{4} \&$ Guglielmone, A. A. ${ }^{4}$
}

\begin{abstract}
RESUMEN
Durante 2003-2004 se obtuvieron garrapatas de caballos (Amblyomma neumanni) y de corzuela, Mazama gouazoupira (A. neumanni y Haemaphysalis juxtakochi) en Catamarca y de perros (A. tigrinum, Rhipicephalus sanguineus), mara, Dolichotis patagonum ( $R$. sanguineus), lampalagua, Boa constrictor (Amblyomma argentinae) y tapir, Tapirus terrestris (Amblyomma dubitatum) en Tucumán. Aunque $R$. sanguineus se presume que se encuentra establecida en la mayor parte de los centros urbanos argentinos, éstos son los primeros registros para Tucumán. El hallazgo sobre mara es el primero para este tipo de hospedador. También los registros de A. dubitatum y de H. juxtakochi en Tucumán y Catamarca, respectivamente, son los primeros para ambas provincias.

Palabras clave: garrapatas, Ixodidae, Amblyomma, Haemaphysalis, Rhipicephalus, Catamarca, Tucumán, Argentina.
\end{abstract}

\section{SUMMARY}

\section{Ticks from Catamarca and Tucumán provinces: study of a collection from wild and domestic hosts.}

During 2003-2004 samples of ticks were obtained from horses (Amblyomma neumanni) and a gray brocket deer, Mazama gouazoupira (A. neumanni and Haemaphysalis juxtakochi) in Catamarca, and from dogs (A. tigrinum, Rhipicephalus sanguineus), mara, Dolichotis patagonum (R. sanguineus), boa, Boa constrictor (Amblyomma argentinae) and tapir, Tapirus terrestris (Amblyomma dubitatum) in Tucumán. Although R. sanguineus is presumably established in most Argentinean localities, these are the first records for Tucumàn. Its finding on a mara is a new host record. As well, the findings of A. dubitatum and $H$. juxtakochi in Tucumán and Catamarca, respectively, are also the firsts for these provinces.

Key words: ticks, Ixodidae, Amblyomma, Haemaphysalis, Rhipicephalus, Catamarca, Tucumán, Argentina.

1.- Facultad de Veterinaria, Universidad Juan Agustín Maza. (5500) Mendoza.

E-mail: corina_zerpa@hotmail.com

2.- Facultad de Veterinaria, Alberto Lasplaces 1550. (11600) Montevideo, Uruguay.

3.- Veterinaria Perros y Gatos, Las Piedras 1380. (3000) San Miguel de Tucumán.

4.- INTA-EEA Rafaela, C.C. 22. (2300) Rafaela, provincia de Santa Fe.

Manuscrito recibido el 30 de junio de 2004 y aceptado para su publicación el 20 de octubre de 2004. 